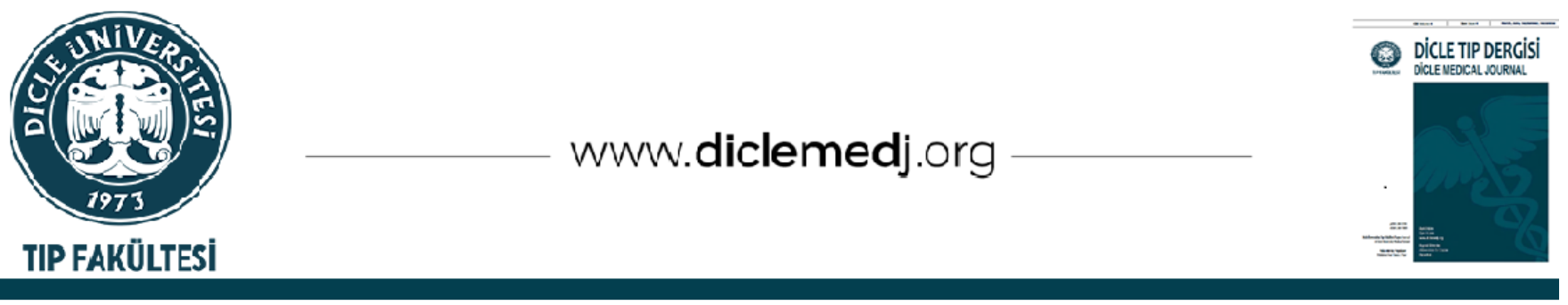

\title{
Bir Üniversite Hastanesi Çocuk ve Ergen Ruh Sağlığı Ve Hastalıkları Kliniğinde Değerlendirilen Adli Olguların Sosyodemografik ve Klinik Özelliklerinin İncelenmesi
}

\author{
Mehmet Karadag ${ }^{1}$, Canan Akkaya ${ }^{1}{ }_{1}$, Aslıhan Gümüşlü ${ }^{i}{ }_{2}$, Zehra Topal ${ }^{i}{ }_{1}$, Cem Gokcen ${ }_{1}$ \\ 1 Gaziantep Üniversitesi Tıp Fakültesi Çocuk ve Ergen Ruh Sağlığı ve Hastalıkları Anabilim Dalı, Gaziantep, Türkiye \\ 2 Gaziantep Üniversitesi Tıp Fakültesi Ruh Sağlı̆ı ve Hastalıkları Anabilim Dalı, Gaziantep, Türkiye
}

Geliş: 14.09.2020; Revizyon: 21.02.2021; Kabul Tarihi: 22.02.2021

Öz

Amaç: Bu çalışmada, adli makamlarca Gaziantep Üniversitesi Tıp Fakültesi Çocuk ve Ergen Psikiyatrisi Kliniğine yönlendirilen çocukların sosyodemografik özelliklerinin belirlenmesi, mevcut psikopatolojilerin tespiti ve adli rapor istem nedenlerinin tanımlanarak kliniğimiz tarafından düzenlenen raporların geriye dönük incelenmesi amaçlanmaktadır.

Yöntemler: Ocak 2018- Ocak 2020 tarihleri arasında Gaziantep Üniversitesi Tıp Fakültesi Çocuk ve Ergen Psikiyatrisi Anabilim Dalı'na adli psikiyatrik değerlendirme amacıyla yönlendirilen 177 olgunun dosyası geriye dönük incelenmiştir. Analizlere olguların sosyodemografik verileri, DSM-5'e göre klinik tanıları, adli olayların içerikleri ve verilen kararlar dahil edilmiştir.

Bulgular: Toplam vakaların \%57,6’sı suça sürüklenen, \%42,3'ü mağdur çocuklardan oluşmaktaydı. Suça sürüklenen çocukların \%86,3'ü erkek olup yaş ortalaması 15,4 iken, mağdurların \%70,7'si kız cinsiyetteydi ve yaş ortalaması 13,3'dü. Suça sürüklenen çocuklar en sık hırsızlık (\%36), mağdurlar ise cinsel istismar (\%74,3) sebebi ile psikiyatrik değerlendirmeye alınmıştı. Adli makamlar tarafından suça sürüklenen çocuklar hakkında sıklıkla "işlediği fiilin hukuki anlam ve sonuçlarını algılama ve bu fiille ilgili olarak davranışlarını yönlendirme yeteneğinin yeterince gelişip gelişmediği” (\%96,1) hususunda; mağdurlarda ise "beyanlarına itibar edilip edilemeyeceği" (\%62) hususunda adli rapor istemi yapılmıştır. Suça sürüklenen çocukların \%44,8'inin işlediği iddia edilen fiilin hukuki anlam ve sonuçlarını algılama ve bu fiille ilgili davranışlarını yönlendirme yeteneğinin geliştiği yönünde tıbbi kanaat bildirilirken; mağdurlara sorulan maruz kaldığı fiile karşı bedenen ve ruhen kendini savunabilecek durumda olup olmadığı sorusuna ise \%89,3 oranında ruhen ve bedenen kendini savunamayacağı yönünde tıbbi kanaat bildirilmiştir.

Sonuç: Çocukların gün geçtikçe adli olaylara daha fazla dahil olması ve düzenlenen raporların bu çocukların hayatının akışını ciddi derecede etkileyen kararların verilmesinde yönlendirici olması adli psikiyatrik değerlendirmenin önemini artırmaktadır.

Anahtar kelimeler: Adli psikiyatri, çocuk psikiyatrisi, suça sürüklenen çocuk, cinsel istismar

DOI: 10.5798/dicletip.887702

Correspondence / Yazışma Adresi: Mehmet Karadağ, Gaziantep Üniversitesi Tıp Fakültesi Çocuk ve Ergen Ruh Sağlığı ve Hastalıkları Anabilim Dalı, Gaziantep, Türkiye e-mail: karadagm@gantep.edu.tr 


\section{Investigation Of Sociodemographic And Clinical Features Of Forensic Cases Evaluated In A University Hospital Child And Adolescent Psychiatry Clinic}

\section{Abstract}

Objective: We aimed to determine the sociodemographic characteristics of children who are referred to the Gaziantep University Faculty of Medicine Child and Adolescent Psychiatry Clinic by the judicial authorities, to determine the causes of forensic reports and to examine the reports prepared by our clinic retrospectively.

Method: The files of 177 patients who were referred to Gaziantep University Faculty of Medicine Department of Child and Adolescent Psychiatry between January 2018 and January 2020 for forensic psychiatric evaluation were examined retrospectively. The analysis included sociodemographic data of the cases, clinical diagnoses according to DSM-5, content of judicial events and decisions made.

Results: $57.6 \%$ of the total cases were delinquent child and $42.3 \%$ were victims. While $86.3 \%$ of the delinquent child were boys and the average age was $15.4,70.7 \%$ of the victims were female and the average age was 13.3 . Delinquent child were taken into psychiatric evaluation most frequently due to theft (36\%) and victims were taken into psychiatric evaluation due to sexual abuse (74.3\%). Forensic authorities frequently asked about " whether the ability to perceive the legal meaning and consequences of the act and to direct the behavior in relation to this act is sufficiently developed " (96.1\%); The victims asked for a judicial report on "whether their statements will be trusted" (62\%). While medical opinion is reported that $44.8 \%$ of the delinquent children have the ability to perceive the legal meanings and consequences of the alleged act and to direct their behavior related to this act; In the question of whether the victims are able to defend themselves physically and spiritually against the act they are exposed to, the medical opinion is reported that $89.3 \%$ of them cannot defend themselves spiritually and physically.

Conclusion: Children are getting more involved in forensic events day by day and the fact that the reports about these children are guiding in making decisions that seriously affect the flow of their lives increases the importance of forensic psychiatric evaluation.

Keywords: Forensic psychiatry, child psychiatry, delinquent child, sexual abuse.

\section{GíRiş}

Adli tıp, hukuk ile tıbbın kesiştiği, tıpla alakalı hukuk konularını inceleyen, adli toksikoloji, adli patoloji ve adli psikiyatri başta olmak üzere birçok bilim ve mesleği içeren multidisipliner bir bilim dalıdır. Adli psikiyatri ise kişinin gerçeği değerlendirme yetisini etkileyen klinik tablolar başta olmak üzere yasal boyutlarda ele alınan çeşitli konuları inceleyen, adli süreçlerde bu konularla ilgili sorulara cevap arayan ve bilirkişilik yapan disiplinler arası bir bölümdür ${ }^{1}$. Çocukların adli psikiyatrik değerlendirilmesi çocuk adalet sisteminin önemli bir parçasıdır ve çocukların her geçen gün adli olaylara daha fazla dahil olması çocuk psikiyatri uzmanlığında adli psikiyatri eğitiminin önemini artırmaktadır.
Çocuk ve ergenler adli makamlar tarafindan sıklıkla suça sürüklendiklerinde, fiziksel veya cinsel istismar mağduru olduklarında adli psikiyatrik değerlendirme amacıyla çocuk psikiyatri kliniğine yönlendirilmektedir. Erken evlilik, vasi tayin edilmesi ve velayet davaları da adli psikiyatrik değerlendirme gerektiren diğer konulardır². Adli psikiyatri alanında başlıca: Türk Ceza Kanunu'nun (TCK) 31/2. maddesi kapsamında ceza sorumluluğunun tespiti, cinsel dokunulmazlık ve beden dokunulmazlığına karşı suçlarda TCK 102/3-a. maddesi kapsamında mağdurun kendisini bedenen veya ruhen savunabilip savunamayacağı ve beyanına itibar edilip edilemeyeceği hususları değerlendirilmektedir ${ }^{3}$. Suça sürüklenen çocuk, kanunlarca suç olan bir fiili işlediği iddia edilen ve bu nedenle hakkında soruşturma ya da kovuşturma yapılan veya güvenlik tedbiri uygulanması kararı verilen çocuktur ${ }^{4}$. Türkiye 
İstatistik Kurumu (TÜİK)'na göre güvenlik merkezlerine başvuran çocukların sayısı 2017 yılında 2016'ya kıyasla 1000'de 5 artış göstererek 335.242'ye ulaşmış ve başvuruların \%32,2'sini suça sürüklenen çocukların oluşturduğu tespit edilmiştir. Bu çocukların $\% 24,8$ 'ine hırsızlık, \%34,4'üne yaralama suçları isnat edilmiştir ${ }^{5}$. Çocuk suçluluğunun biyolojik, sosyolojik, psikolojik birçok risk faktörü bulunmakta ve bireye özgü risk faktörlerinde erkek cinsiyet, düşük zeka düzeyi, yüksek dürtüsellik, yıkıcı davranış sorunu varlığı dikkat çekmektedir6. Ayrıca bir çalışmada 5-12 yaş arasında Dikkat Eksikliği Hiperaktivite Bozukluğu (DEHB) belirtileri gösteren çocukların ileride daha çok suç davranışında bulunduğu gösterilmiștir7.

Adli psikiyatrik değerlendirme gerektiren önemli bir diğer konu çocuğun cinsel istismarıdır ${ }^{3}$. Cinsel istismar olarak değerlendirilen eylemler arasında cinsel penetrasyon, interfemoral ilişki, oral-genital temas, cinsel organlara doğrudan veya kıyafetler üzerinden temas, teşhircilik veya çocukları yetişkinlere yönelik cinsel aktivitelere veya pornografiye maruz bırakma ve çocuğun fuhuş ve pornografi amaciyla kullanımı bulunmaktadır8. 1982 ile 2008 yıllarını kapsayan 217 çalışmanın verilerinin metaanalizine göre çocuğun cinsel istismarı yaygınlığ olarak bulunmuştur ${ }^{9}$. Ülkemizde çocuk cinsel istismarının yaygınlığ birlikte TÜIK'in 2017 verilerine göre emniyet birimlerine başvuran çocukların \%46,2'sini mağdur çocukların oluşturduğu, mağdur çocukların ise $\% 13,5^{\prime}$ inin cinsel suç mağduru olduğu görülmüştür6. Çocuğun cinsel istismarı ergenlik ve yetişkinlikte ruhsal hastalık gelişimi, davranış sorunları geliştirme, daha fazla suça karışma ve kendine zarar verici davranışlarda bulunma açısından önemli bir risk oluşturmaktadır ${ }^{10}$. Yapılan bir araştırmada cinsel istismar mağduru çocuklarda en sık Travma Sonrası Stres Bozukluğu (TSSB) $(\% 24,5)$ tanısı konulmuş; bunu \%16,0 ile uyum bozukluğu ve $\% 11,3$ ile akut stres bozukluğu tanıları izlemiştir ${ }^{11}$.

Suça sürüklenen çocuklar hakkında düzenlenen adli psikiyatrik raporlar bu çocukların hayatının akışını ciddi derecede etkileyen kararların verilmesinde yönlendirici olurken, mağdur çocuklar için ise düzenlenen raporlar çocukların maruz kaldıkları suçun cezalandırılmasında ve bu doğrultuda benzer suçların işlenmesinin önlenmesinde kilit taşı olabilmektedir. Bu çalışmada, Ocak 2018- Ocak 2020 tarihleri arasında adli makamlar tarafindan adli rapor istemiyle Gaziantep Üniversitesi Tip Fakültesi Çocuk ve Ergen Psikiyatrisi Kliniğine yönlendirilen mağdur ve suça sürüklenen çocukların sosyodemografik özelliklerinin belirlenmesi, var olan psikopatolojilerin tespiti ve adli rapor istem nedenlerinin tanımlanarak kliniğimiz tarafından düzenlenen raporların geriye dönük olarak incelenmiştir. Çalışmamızın güncel verileri içermesi, hem suça sürüklenen çocukların hem de mağdur çocukların çalışmaya dahil edilmesi sebebiyle literatüre katkı sağlayacağı düşünülmektedir.

\section{YÖNTEMLER}

Bu çalışmada, Ocak 2018- Ocak 2020 tarihleri arasında Gaziantep Üniversitesi Tip Fakültesi Çocuk ve Ergen Psikiyatrisi Anabilim Dalı'na adli psikiyatrik değerlendirme amacıyla yönlendirilen 177 olgunun adli raporları geriye dönük incelenmiştir. Olguların yaş, cinsiyet, zeka düzeyi, aktif psikopatoloji varlığı, dahil oldukları adli olayın niteliği, adli makamlar tarafindan adli rapor düzenlenmesi istenilen konular ve kliniğimizce verilen cevaplar gözden geçirilmiş̧tir. Araştırmaya katılan olgulara çocuk ve ergen psikiyatrisi uzmanlarından oluşan adli psikiyatri heyetinde DSM-5'e göre yapılan klinik görüşme sonucunda tanı konulmuştur. Araştırmaya katılan olgulara

mental durum değerlendirmesi amaciyla psikolog eşliğinde psikometrik ölçümler (Porteus Labirent Testi veya Kent EGY testi) uygulanmış ve psikometik ölçümler ile klinik görüşme sonucunda oluşan klinisyen görüşü korele edilerek nihai karar verilmiştir. Örneklemimizde en sık tespit edilen psikiyatrik tanılar Tablo I'de yer almaktadır. Bir olguda birden çok psikiyatrik tanı olabilir. Çalışmaya 18 yaş altı olan çocuklar dahil edilmiş 
olup herhangi bir dişlanma kriteri Üniversitesi Etik Kurulu'ndan onay alınmıştır bulunmamaktadır. Çalışma için Gaziantep (Tarih: 27.08.2020 Sayı: 238).

Tablo I: Kliniğimize başvuran adli olguların sosyodemografik özellikleri ve dahil oldukları adli olayların nitelikleri

\begin{tabular}{|c|c|c|c|}
\hline & Suça Sürüklenen Çocuk (n:102) & Mağdur (n:75) & $\mathbf{P}$ \\
\hline Başvuru Yaşı & 15.4 ( $\pm 2.7 ;$ min:6 max:25) & 13.3 ( $\pm 3.4 ;$ min:5 max: 18$)$ & $\mathrm{P}<0.001$ \\
\hline Olay Tarihindeki Yaşı & 13.7 ( $\pm 1.6 ;$ min:7 max:20) & 11.6( \pm 3.3 ; min:5 max:17) & $P<0.001$ \\
\hline \multicolumn{4}{|l|}{ Cinsiyet } \\
\hline Kız & $14(\% 13.7)$ & $53(\% 70.7)$ & $\mathrm{P}<0.001$ \\
\hline Erkek & $88(\% 86.3)$ & $22(\% 29.3)$ & \\
\hline \multicolumn{4}{|l|}{ Psikiyatrik Tanı } \\
\hline Yok & $39(\% 78)$ & $37(\% 49.3)$ & \\
\hline DEHB* & $6(\% 12)$ & $3(\% 4)$ & \\
\hline Davranım Bozukluğu & $1(\% 2)$ & $1(\% 1.3)$ & \\
\hline Madde Kullanım Bozukluğu & $3(\% 6)$ & $0(\% 0)$ & \\
\hline Dürtü Kontrol Bozukluğu & $1(\% 2)$ & $2(\% 2.7)$ & $\mathrm{P}=0.522$ \\
\hline $\mathrm{TSSB}^{* *}$ & $0(\% 0)$ & $1(\% 2.7)$ & \\
\hline \multicolumn{4}{|l|}{ Zeka düzeyi } \\
\hline Normal & $48(\% 70.6)$ & $38(\% 69.1)$ & \\
\hline Sinırda Mental Kapasite & $12(\% 17.6)$ & $10(\% 18.2)$ & \\
\hline Hafif Düzeyde MR*** & $6(\% 8.8)$ & $6(\% 10.9)$ & $\mathrm{P}=0.865$ \\
\hline Orta Düzeyde $\mathrm{MR}^{* * *}$ & $2(\% 2.9)$ & $1(\% 1.8)$ & \\
\hline \multicolumn{4}{|l|}{ Adli Olayın Niteliği } \\
\hline & \multicolumn{2}{|c|}{ Cinsel İstismar } & \\
\hline & $36(\% 36)$ & $4(\% 5.4)$ & \\
\hline Hirsızlık & $6(\% 6)$ & $8(\% 10.8)$ & \\
\hline \multicolumn{4}{|l|}{ Darp-Tehdit } \\
\hline \multicolumn{4}{|c|}{ Kişiyi Hürriyetinden Yoksun Kılma } \\
\hline \multicolumn{4}{|l|}{ Yaralama-Öldürme } \\
\hline & $13(\% 13)$ & $2(\% 2.7)$ & \\
\hline Terör & $4(\% 4)$ & $0(\% 0)$ & $P<0.001$ \\
\hline Uyuşturucu Madde Ticareti & 12 (\%12) & $0(\% 0)$ & \\
\hline Diğer & $6(\% 6)$ & $1(\% 1.3)$ & \\
\hline
\end{tabular}

*DEHB: Dikkat Eksikliği Hiperaktivite Bozukluğu, ${ }^{* *} T S S B:$ Travma Sonrası Stres Bozukluğu, ${ }^{* * * M R: ~ M e n t a l ~ R e t a r d a s y o n ~}$ 
Tablo II'de hakkında en sık adli rapor düzenlenmesi istenen üç konu (TCK 31/2 kapsamında suça sürüklenen çocuklara işlediği iddia edilen fiilin hukuki anlam ve sonuçlarını algılama veya davranışlarını yönlendirme yeteneğinin gelişip gelişmediği, TCK 102/3-a kapsamında mağdurun kendini savunabilecek durumda olup olmadığı ve adli psikiyatrik değerlendirme amacıyla gönderilen çocuğun beyanına itibar edilip edilemeyeceği hakkında) ve bu konularla ilgili cevapların yer aldığ istatistikler eklenmiştir. Rıza açıklamaya ehil olup olmadığı, akıl ruh sağlığının yerinde olup olmadı̆̆ı, olay sonrası akıl ruh sağlığının bozulup bozulmadığı, çocuğun zeka düzeyinin yabancı kişiler tarafından anlaşılır olup olmadığı hususunda düzenlenmesi istenilen raporlar ise diğer başlığı altında toplanmıştır. Tablo II'deki tanımlar Çocuk ve Ergen Psikiyatrisi Derneği, Çocuk ve Ergen Ruh Sağlığı ve Hastalıkları kitabı, adli psikiyatri bölümünde tarif edildiği şekilde yapılmıştır'12.

Tablo II: Adli rapor istem nedenleri ve kliniğimizde verilen adli rapor sonuçlarının dağılımı

\begin{tabular}{|c|c|c|}
\hline Mahkeme Soruları & $\begin{array}{l}\text { Suça Sürüklenen } \\
\text { Çocuk(soru } \\
\text { sayısı/yüzde) }\end{array}$ & $\begin{array}{l}\text { Mağdur } \\
\text { (soru } \\
\text { sayısı/yüzde) }\end{array}$ \\
\hline TCK 31/2a & $98(\% 91.5)$ & $25(\% 21.5)$ \\
\hline TCK $102 / 3 a^{b}$ & $1(\% 1)$ & $28(\% 24.3)$ \\
\hline İfadesine güvenilir mi? & $3(\% 2.8)$ & $47(\% 40.5)$ \\
\hline Diğer & $5(\% 4.7)$ & 16 (\%13.7) \\
\hline \multicolumn{3}{|l|}{$\begin{array}{l}\text { TCK 31/2a kapsamında } \\
\text { değerlendirme }\end{array}$} \\
\hline Bilir yönlendirir & $43(\% 44.8)$ & $3(\% 13)$ \\
\hline Bilir yönlendiremez & $19(\% 19.8)$ & $1(\% 4.3)$ \\
\hline Bilmez yönlendiremez & $34(\% 35.4)$ & $19(\% 82.7)$ \\
\hline \multicolumn{3}{|c|}{$\begin{array}{l}\text { TCK102/3- } \mathrm{a}^{\mathrm{b}} \text { kapsamında } \\
\text { değerlendirme }\end{array}$} \\
\hline \multicolumn{3}{|l|}{ Kendini savunabilir } \\
\hline \multirow{2}{*}{ Kendini savunamaz } & $0(\% 0)$ & $3(\% 10.7)$ \\
\hline & $1(\% 100)$ & $25(\% 89.3)$ \\
\hline \multicolumn{3}{|c|}{ İfadelerine güvenilir mi? } \\
\hline Evet & $3(\% 100)$ & $46(\% 100)$ \\
\hline Hayır & $0(\% 0)$ & $0(\% 0)$ \\
\hline Diğer sorular & $7(\% 6.9)$ & 17 (\%22.7) \\
\hline
\end{tabular}

b TCK 102/3-a Mağdurun maruz kaldığı iddia edilen fiile karşı kendini savunabilecek durumda olup olmadığı hususunda rapor düzenlenilmesi istenilen olgular

\section{İstatistiksel Analiz}

Tanımlayıcı istatistik olarak verilerin uygunluğuna göre ortalama, standart sapma, median, min-maks, sayı ve yüzde değerleri verilmiştir. Normal dağılan veriler için; grup karşılaştırmalarında bağımsız gruplar t-testi, önce-sonra karşılaştırmalarında eş gruplar ttesti; normal dağılmayan veriler için grup karşılaştırmalarında Mann-Whitney U t-testi kullanılmıştır. Veriler SPSS 25.0 İstatistiksel Paket Programı kullanılarak değerlendirilmiştir. Anlamlılık düzeyi $\mathrm{p}<0.05$ olarak seçilmiştir.

\section{BULGULAR}

Araştırmamıza dahil edilen suça sürüklenen çocukların yaş ortalaması 15,4; mağdur çocukların ise 13,3'dü. Adli psikiyatrik değerlendirme amacıyla çocuk psikiyatri kliniğine yapılan başvurular ile ilgili adli olay tarihleri arasında ortalama 2 yıl bulunmaktadır. Suça sürüklenen çocukların adli olay tarihindeki yaş ortalaması 13,7; mağdur çocukların ise 11,6'ydı. Suça sürüklenen çocukların büyük çoğunluğu erkek $(\% 86,3)$ iken, mağdurların büyük çoğunluğu kızlardan $(\% 70,7)$ oluşuyordu. Değerlendirilen adli olguların büyük çoğunluğunda aktif bir psikopatoloji saptanmadı. DSM-5 tanı kriterlerine göre yapılan görüșmelerde en sık saptanan psikiyatrik tanı DEHB'idi. Yapılan mental durum değerlendirmesinde suça sürüklenen çocukların \%29,4'ünde; mağdurların ise \%30,9'unda herhangi bir mental retardasyon bulgusu mevcuttu. Çocukların karıştığı adli olayların niteliği incelendiğinde, suça sürüklenen çocuklar en sık hırsızlık (\%36) sebebi ile, mağdurlar ise cinsel istismar $(\% 74,3)$ sebebi ile psikiyatrik değerlendirmeye alınmıştı. Cinsel istismar mağduru olan çocukların \%80'ini $(\mathrm{n}=44) \mathrm{kız}$ çocuklar, \%20'sini $(n=11)$ ise erkek çocuklar 
oluşturuyordu. Cinsel istismar mağduriyeti nedeniyle başvurular en küçük 5 en büyük yaş 18 yaşında gerçekleşmişti. Cinsel istismar mağduru çocukların olay tarihindeki ortalama yaşı 11,5 $( \pm 3,60)$; adli değerlendirmeye alınma tarihindeki ortalama yaşı 13,75 ( $\pm 3,24)$ 'idi. Olaydan adli değerlendirmeye kadar geçen süre ortalama 2,2 \pm 2,9 (min: 0 maks:10,0) yldı. Cinsel istismar mağduru olma haricinde çocuklar; darp/tehdit (\%10.8), kişiyi hürriyetinden yoksun kılma $(\% 5,4)$, hırsızlık $(\% 5,4)$, yaralama/öldürme $(\% 2,7)$ suçlarının mağduru olarak başvurmuştu. Başvuran adli olguların sosyodemografik özellikleri ve dahil oldukları adli olayların nitelikleri Tablo I'de ayrıntılı olarak verilmiştir. Suça sürüklenen çocuklar ile mağdurlar arasında yapılan karşılaştırmada istatistiki olarak anlamlı olmak üzere mağdurların yaşının daha küçük olduğu, kız cinsiyetin ağırlıklı olduğu saptanmıştır. Ayrıca suça sürüklenen çocuklar ile mağdurların dahil oldukları adli olay niteliklerinin istatistiksel olarak anlaml seviyede birbirinden farklı olduğu saptanmıştır $(\mathrm{p}<0.001)$.

Tablo II'de Adli makamlar tarafindan adli psikiyatrik değerlendirme amacıyla kliniğimize yönlendirilen çocuk ve ergenler hakkında adli rapor istem nedenleri ve kliniğimizde düzenlenen adli rapor sonuçları yer almaktadır. Adli makamlar tarafindan suça sürüklenen çocuklar hakkında en sık TCK 31/2 kapsamında yer alan "işlediği iddia edilen fiilin hukuki anlam ve sonuçlarını algılama veya bu fiille ilgili davranışlarını yönlendirme yeteneğinin yeterince gelişip gelișmediği" (\%96,1) hususunda; mağdurlarda ise en sik "beyanlarına itibar edilip edilemeyeceği" (\%62) hususunda adli rapor istemi yapılmıştır.

Yapılan değerlendirmenin ardından suça sürüklenen çocukların \%44,8'inin işlediği iddia edilen fiilin hukuki anlam ve sonuçlarını algılama ve bu fiille ilgili davranışlarını yönlendirme yeteneğinin geliștiği, \%35,4'ünün ise hem işlediği iddia edilen fiilin hukuki anlam ve sonuçları anlama hem de bu fiille ilgili olarak davranışlarını yönlendirme yeteneğinin yeterince gelişmediği tıbbi kanaatine varılmıştır. Sıklıkla mağdurlara sorulan maruz kaldığı fiile karşı ruhsal ve bedensel açıdan kendini savunabilecek durumda olup olmadığ sorusuna ise \%89,3 oranında ruhsal ve bedensel açıdan kendini savunamayacağ yönünde tıbbi kanaat bildirilmiştir. Mağdur ve suça sürüklenen çocukların vermiş oldukları ifadelerin güvenilirliğinin sorgulandığı durumlarda ise hem mağdurların hem de suça sürüklenen çocukların ifadelerine güvenilebileceği belirtilmiștir.

\section{TARTIŞMA}

Çalışmamız hem mağdur hem de suça sürüklenen çocukların birlikte incelenmesi açısından önem arz etmektedir. Suça sürüklenen çocukların olay tarihindeki yaş ortalaması 13,7 olup olguların büyük çoğunluğunu erkekler $\quad(\% 86,3)$ oluşturmaktaydı. Ayaz ve arkadaşlarının yapmış olduğu bir çalışmada suça sürüklenen çocukların yaş ortalamasının 13,9 olduğu ve \%86,3 ile erkek cinsiyetin baskın olduğu bulunmuştur ${ }^{3}$. Ülkemizde çeşitli merkezlerde yapılan benzer çalışmalarda da bizim çalışmamızdaki gibi suça sürüklenen çocuklar arasında erkek cinsiyet yoğunluğunun olduğu gösterilmiştir ${ }^{13,14}$ Çeşitli ülkelerdeki çalışmalar, suça sürüklenen çocuklar arasındaki cinsiyet farklılığını doğrulamıştır. Amerika Birleşik Devletleri'nde yapılan çalışmada, erkekler arasındaki şiddet içeren suç işleme oranı kızlardan dört kat, tutuklama oranı ise iki kat daha yüksek bulunmuştur ${ }^{15}$. Bu konuda yapılan çalışmalara göre çocuk suçluluğunda erkek cinsiyetin önemli bir risk faktörü olmasında erkeklerde öfke dışavurumunun daha fazla olması, erkeklerin daha çok riskli davranışlarda bulunması, daha fazla fiziksel agresyon göstermeleri ve toplumsal cinsiyet rolleri etkili olmaktadır ${ }^{16}$. 
DEHB ile kural ihlali davranışı arasında bir ilişki olduğuna dair kanıtlar giderek artmaktadır ve DEHB olan kişilerin yasal sisteme dahil olma olasılığı normal popülasyona göre daha yüksektir ${ }^{17} .2012$ yılında yapılan bir metaanalizde ise tüm dünyadaki DEHB prevalansı \%5,9-7,1 olarak bulunmuştur ${ }^{18}$. Cezaevi örneklemlerinde DEHB yaygınlığını araştıran çalışmaların meta-analizinde ise prevalans oranı \%25,5 olarak bulunmuş, ayrıca DEHB alt tipine göre fark olmaksızın, bu çocukların ileride suça karışma ihtimalinin yüksek olduğu belirtilmiştir ${ }^{19}$. Literatür ile benzer şekilde bizim çalışmamızda da suça sürüklenen çocuklarda saptanan en sik psikopatoloji DEHB (\%12) idi. Ülkemizde yapılan bazı tanımlayıcı araştırmalarda da bulgularımızla uyumlu olarak suça sürüklenen çocuklarda en sık DEHB saptanmıştı ${ }^{13,20}$. DEHB davranım bozukluğu ile sıklıkla birlikte görülmekte ve bu iki bozukluğun ortak genetik etiyolojiyi paylaştığı bilinmektedir ${ }^{21}$. DEHB'nin dürtüsel doğası, davranım bozukluğu, karşıt olma karşı gelme bozukluğu, madde kullanım bozukluğu gibi DEHB'ye sıklıkla eşlik eden ve suç davranışıyla ilişkili komorbid durumlar, DEHB tanılı çocukların daha fazla şiddet içeren tutumlar sergilemesi ve suç davranışı sergileyen çocuklarla daha fazla arkadaşlık edinmeleri gibi birçok neden bu çocukların suça karışma ihtimalini artırmaktadır ${ }^{22}$.

Duygusal ve bilişsel gelişimin, sosyal kuralların öğrenilmesi ve sosyal davranışları kontrol etme yeteneği ile ilişkili olarak erken suçluluğun gelişmesinde önemli bir rol oynadığ bilinmektedir ${ }^{23}$. Literatürde nörogelişimsel bozuklukların incelemesinde, çocuk ve ergen suçlular arasında zihinsel engellilik prevalansının (\%23-32) genel nüfustaki zihinsel engellilik prevalansına (\%2-4) göre yüksek olduğunu gösterilmiştir ${ }^{24}$. Çalışmamızda da literatürle uyumlu olarak suça sürüklenen çocukların \%29,4'ünün herhangi bir mental retardasyon bulgusu mevcuttu. Mental retardasyonu olan çocukların suça karışma eğilimlerinin fazlalığı, bu çocukların daha çok korunma ihtiyacı olduğunu göstermekte, rehabilitasyon eğitimleriyle desteklenerek topluma kazandırılmasının önemini gözler önüne sermektedir.

Suça sürüklenen çocukların işlediği iddia edilen suçun nitelikleri değerlendirildiğinde birçok çalışmada en sık hırsızlık suçuna rastlanmış, hırsızlığ görülmüştür12,20. Çalışmamızda da bu çalışmalarla uyumlu olarak suça sürüklenen çocukların en sık hırsızlık (\%36) suçuna karıștığı, farklı olarak ise ikinci sıklıkta cinsel istismar (\%21) suçuna karıştığı görüldü. Akran istismarı nedeniyle yargılanan çocukların değerlendirildiği bir çalışmada bu çocukların en sık mala karşı işlenen suçlar $(\% 50,5)$ ve cinsel suçlar $(\% 39,8)$ ile yargılandığı; cinsel suçlar kapsamında değerlendirilen suçların ise $\% 62,16$ 'sını çocuğun cinsel istismarı, $\% 12,16$ 'sını reşit olmayanla cinsel ilişki suçunun oluşturduğu gösterilmiştir ${ }^{25}$. Bağ ve arkadaşlarının çocuk izlem merkezinde yaptığı bir çalışmada cinsel istismar mağduru olan çocukların en sı başvuru nedeninin \%38 oranında arkadaş ya da sevgili arasında gerçekleșen cinsel denemeler neticesinde olduğu bulunmuştur ${ }^{26}$. Suça sürüklenen çocukların yaş ortalamasının sıklıkla ergenlik dönemine tekabül etmesi, akran cinsel istismarının sıklığı, ergenliğin fiziksel olarak erişkine benzer bir dönem olması fakat bilişsel gelişim ve ruhsal olgunluk açısından cinsel istismara risk teşkil etmesi nedeniyle gençlerin cinsel istismar suçuna sürüklenme ihtimalinin arttığı söylenebilir.

Ceza sorumluluğunun belirlenmesi suça sürüklenen çocukların adli değerlendirmesinde kilit noktadır ve adli makamlarca en sık adli rapor istem nedenlerinden biridir. Çalışmamızda suça sürüklenen çocukların $\% 44,8$ 'inin işlediği iddia edilen fiilin hukuki anlam ve sonuçlarını algılama ve bu fille ilgili 
davranışlarını yönlendirme yeteneğinin geliştiği yönünde rapor düzenlendiği tespit edildi. Çeşitli illerde yapılan benzer çalışmalarda suça sürüklenen çocukların ceza sorumluluğun geliştiği yönündeki raporların oranları \%23,5 ile \%75 arasında değişkenlik göstermektedir ${ }^{13,14}$. Bulguların bu denli değişkenlik göstermesi çocuk ve ergen psikiyatrisi ihtisasında yapılandırılmış bir adli psikiyatri eğitiminin olmaması, muayenelerde objektif kriterlerin bulunmaması ve dolayısıyla klinisyenlerin görüş farklılıkları içermesinden kaynaklanıyor olabilir.

Kliniğimizde değerlendirilen adli olguların \%42,4'ünü $\quad(n=75) \quad$ mağdur çocuklar oluşturuyordu. 55 çocuk cinsel istismar, 8 çocuk darp/tehdit, 8 çocuk hırsızlık, 4 çocuk ise kişiyi hürriyetinden yoksun kılma suçlarının mağduruydu. TÜİK verilerine göre 2017 yılında güvenlik merkezlerine çocuk mağdur olarak başvuran 137.482 vakanın \%59,1 ile en yüksek oranda yaralama mağduru olduğu, bunu \%13,5 ile cinsel suç mağduriyetinin izlediği gösterilmiştir. Diğer çocukların ise daha az oranlarda olmak üzere aile düzenine karşı suçlar $(\% 6,8)$, tehdit $(\% 3,8)$, hırsızlık $(\% 3,7)$, kişiyi hürriyetinden yoksun kılma $(\% 3,1)$ suçlarından mağdur olduğu gösterilmiştir ${ }^{5}$. Literatürde çocuk mağduriyetinde genellikle cinsel istismar konusu ele alınırken bizim çalışmamızda ve TÜİK verilerinde çocukların cinsel istismar kadar diğer suçlar açısından da azımsanmayacak kadar risk altında olduğu görülmektedir.

Çalışmamızdaki cinsel istismar mağduru çocuk ve ergenlerin 80'ini $(n=44)$ kizların oluşturması, çocuğun cinsel istismarında cinsiyet farklılıklarına dikkat çekmektedir. Literatürde bulgularımızla uyumlu olarak kızların cinsel istismara daha çok maruz kaldığına dair veriler bulunmaktadır ${ }^{26}$. Yapılan bir meta-analiz çalışmasında kızların çocukluk boyunca cinsel istismara uğrama açısından erkeklere kıyasla iki veya üç kat daha fazla risk altında olduğu bildirilmiștir ${ }^{27}$. Çalışmamızda ise kız erkek oranı 4 olarak bulunmuştur. Çocuğun cinsel istismarının prevalans oranları için bildirilen cinsiyet farklılıkları, kızlarda cinsel istismarın daha fazla görülüyor olmasından ya da erkeklerin savunmasız veya kurban/mağdur olarak görünmek istememeleri, "cinsel istismara uğramış" veya "homoseksüel" olarak etiketlenme korkularından dolayı bu deneyimlerini açıklama konusunda daha isteksiz bir tutum sergilemelerinden kaynaklanıyor olabilir ${ }^{28}$.

Çalışmamızda suça sürüklenen çocuklar ile mağdurlar arasında yapılan karşılaștırmada istatistiki olarak anlamlı olmak üzere mağdurların yaşının (ortalama:11.6) daha küçük olduğu, kız cinsiyetin $(\% 70,7)$ ağırlıklı olduğu, dahil oldukları adli olay tipinin farklı olduğu görülmüştür. Konya'da yapılan bir çalışmada da çalışmamızla uyumlu olarak mağdur çocukların yaş ortalamasının suça sürüklenen çocuklardan anlamlı olarak daha küçük olduğu, başvuru nedenlerine bakıldığında erkeklerin suça sürüklenme, kızların ise cinsel istismar grubunda anlaml olmak üzere yüksek olduğu tespit edilmiştir ${ }^{29}$.

Cinsel istismarın doğası gereği çocuklar tarafından açıklanmasının zor olması çoğu vakada suçun ortaya konmasını erişkin yaşama kadar erteleyebilmektedir. Yapılan bir çalışmaya göre çocukluk çağı cinsel istismara uğrama öyküsünü dili getirme, mağdurların \%37'sinde olaydan sonraki 1 yll içinde, $\% 10$ 'unda 1 ila 10 yıl arasında, \%24'ünde 10 yıl veya daha sonrasında gerçekleştirildiği bildirilmektedir ${ }^{30}$. Bizim raporlarımıza göre ise olayın oluş tarihi ve adli değerlendirme tarihi arasındaki süre minimum sıfır maksimum 10 yıldı. Klinik deneyimlerimize göre olayın oluş tarihi ve açığa çıkması arasındaki sürenin uzaması, travmatik olayla ilgili hafıza yanlılıkları veya eksiklikleri adli süreçlerde çocukların ifadelerindeki çelişkileri artırabilmektedir. Çalışmamızda mağdur 
çocuklar adli makamlar tarafından en sık beyana itibar edilip edilemeyeceği $(\% 40,5)$ hususunda değerlendirilmek üzere tarafımıza yönlendirilmişti. Kliniğimizde düzenlenen raporlar incelendiğinde vakaların tamamında çocuğun beyanına itibarı bozacak aktif bir psikopatolojilerinin olmadığı, her birey kadar beyanlarına itibari edilebileceği yönünde tıbbi kanaat bildirildiği görülmektedir. Ülkemizde yapılan bir çalışmada mağdur çocukların en sık "olay sonrası ruh ve beden sağlığının bozulup bozulmadığı" hususunda değerlendirildiği görülmektedir ${ }^{14}$. Haziran 2014 tarihinde TCK 103/6 fikrasında yapılan değişiklikle mağdurun suç neticesinde ruh veya beden sağlığının bozulması durumunda yapılan ceza artırımı uygulaması kaldırılmıștır. Çalışmamızdaki mağdur çocukların değerlendirilme hususlarının sıklığındaki farklılıklar mevcut kanun değişikliği ve vakalarımızın bu değişiklik sonrasındaki olguları kapsıyor olması ile açıklanabilir.

Çalışmanın geriye dönük tasarımı, dosyalarda veri eksikliklerinin olması, olgularla yapılandırılmış bir görüşme yapılamamış olması ve var olan bozuklukların ağırlıklarının ölçeklerle derecelendirilmemesi çalışmamızın kısıtlılıklarını oluşturmaktadır. Ayrıca dahil edilen vaka sayısının nispeten az olması da kısitlılık olarak kabul edilebilir. Sonuç olarak, adli psikiyatrik değerlendirme gerek suça sürüklenen çocukların ceza sorumluluğunun tespiti gerekse de mağdur çocukların haklarının aranması açısından çocuk adalet sisteminde önemli bir yere sahiptir. Çocuk suçluluğunda ve mağduriyetinde etkili olan risk faktörlerini belirlemek, bu davranışları önleme ve çocukların topluma geri kazandırılmasının ilk basamağını oluşturmaktadır. $\mathrm{Bu}$ konuda yapılacak çalışmalara ihtiyaç duyulmaktadır.

Etik Kurul Kararı: Çalışma için Gaziantep Üniversitesi Etik Kurulu'ndan onay alınmıștır (Tarih: 27.08.2020 Sayı: 238).
Çıkar Çatışması Beyanı: Yazarlar çıkar çatışması olmadığını bildirmişlerdir.

Finansal Destek: Bu çalışma her hangi bir fon tarafından desteklenmemiștir.

Declaration of Conflicting Interests: The authors declare that they have no conflict of interest.

Financial Disclosure: No financial support was received.

\section{KAYNAKLAR}

1. Biçer Ü, Tırtıl L, Kurtaş Ö, Aker T. Adli psikiyatri: Birinci Basamakta Adli Tıp, 2. Baskl, İstanbul: İstanbul Tabip Odası, 2011; 242-52.

2. Ayaz M, Ayaz AB, Soylu N. Çocuk ve ergen adli olgularda ruhsal değerlendirme. Klin. Psikiyatr. Derg. 2012; 15: 33-40.

3. Sener MT, Dursun OB, Aydin EF, Arslan S, Gulec M. Brief Report. Area of Specialty Preferences of Forensic Authorities in Forensic Psychiatric Evaluation Requests: A University Hospital Experience. Dusunen Adam. 2014; 27.

4. Ulaşabileceği adreshttps://www.mevzuat.gov.tr/MevzuatMetin/ 1.5.5395.pdf

5. Türkiye Çocuk Suç İstatistikleri 2017 (http://www.tuik.gov.tr/PreHaberBultenleri.do?id $=27609$ )

6. Güler G. Suça sürüklenen çocukların biyopsikososyal değerlendirilmesi. Türkiye Klinikleri J Child Psychiatry-Special Topics, 2017; $3(3), 220-4$.

7. Fletcher J, \& Wolfe B. Long-term consequences of childhood ADHD on criminal activities. J Ment Health Policy Econ. 2009; 12(3), 119.

8. Putnam FW. Ten-year research update review: Child sexual abuse. J Am Acad Child Adolesc Psychiatry. 2003;42: 269-78.

9. Stoltenborgh M, Van Ijzendoorn MH, Euser EM, Bakermans-Kranenburg MJ. A global perspective on child sexual abuse: Meta-analysis of prevalence around the world. Child Maltreat. 2011; 16: 79-101. 
10. Papalia NL, Luebbers S, Ogloff JR, Cutajar M, Mullen PE. The long-term co-occurrence of psychiatric illness and behavioral problems following child sexual abuse. Aust N Z J Psychiatry. 2017; 51: 604-13.

11. Yektaş Ç, Tufan AE, Büken B, Çetin NY, Yazici M. Cinsel istismar mağduru çocuk ve ergenlerde istismar ve istismarclya ilişkin özelliklerin ve psikopataloji ile ilişkili risk etkenlerinin değerlendirilmesi. Anadolu Psikiyatri Derg, 2018; 19: 501-8.

12. Şişmanlar ŞG, Biçer Ü, Coşkun A. Çocuk ve Ergen Ruh Sağlığı ve Hastalıkları, 2. Baskı, Ankara: Türkiye Çocuk ve Genç Psikiyatrisi Derneği Yayınları, 2016: 450-69.

13. Yüksel T. Bir üniversite hastanesi çocuk psikiyatrisi polikliniğinde değerlendirilen suça sürüklenen çocuklar. Dicle Med J. 2019; 46: 559-65.

14. Gümüştaş F, YulafY, Gökçe S, Sağlam S, Kütük EK. Adıyaman ilinde çocuk ve ergen psikiyatrisi polikliniğine yönlendirilen adli olguların bir yıllık geriye dönük incelenmesi. Cukurova Med J. 2014; 39: 280-9.

15. Puzzanchera C, Adams B, Sickmund M. Juvenile Court Statistics 2008. Pittsburgh, PA: National Center for Juvenile Justice. Retrieved from http://www.ncjj.org/pdf/jcsreports/jcs2008.pdf.

16. Baxendale S, Cross D, Johnston R. A review of the evidence on the relationship between gender and adolescents' involvement in violent behavior. Aggress Violent Behav. 2012; 17: 297-310.

17. Philipp-Wiegmann F, Rösler M, Clasen O, et al. ADHD modulates the course of delinquency: a 15year follow-up study of young incarcerated man. Eur Arch Psychiatry Clin Neurosci. 2018; 268: 391-9.

18. Willcutt EG. The prevalence of DSM-IV attentiondeficit/hyperactivity disorder: a meta-analytic review. Neurotherapeutics. 2012; 9: 490-9.

19. Young S, Moss D, Sedgwick O, Fridman M, Hodgkins P. A meta-analysis of the prevalence of attention deficit hyperactivity disorder in incarcerated populations. Psychol med. 2015; 45: 247-58.

20. Eyüboğlu M, Eyüboğlu D. Suça Sürüklenen Çocuklarda Psikiyatrik Bozukluklar,
Sosyodemografik Özellikler ve Risk Faktörleri. Klin Psikiyatr Derg. 2018; 21.

21. Thapar A, Harrington R, McGuffin P. Examining the comorbidity of ADHD-related behaviours and conduct problems using a twin study design. Br J Psychiatry. 2001, 179: 224-9.

22. Gudjonsson GH, Sigurdsson JF, Sigfusdottir ID, Young S. A national epidemiological study of offending and its relationship with ADHD symptoms and associated risk factors. J Atten Disord. 2014; 18: 3-13.

23. Farrington DP, Loeber R: Child delinquents: Development, intervention, and service needs: Sage; 2001.

24. Hughes N. Nobody made the connection: The prevalence of neurodisability in young people who offend. 2012.

25. Şengül HA, Cantürk N, Cantürk G, Dağalp R. Ankara 1. Çocuk Ağır Ceza Mahkemesi'nde akran istismarı nedeniyle yargılanan çocukların değerlendirilmesi. Turk Pediatr Arsivi. 2012; 47.

26. Bağ Ö, Alşen S. Çocuk izlem merkezinde cinsel istismarın değerlendirilmesi: Bir merkezin bir yıllık deneyimi. Anadolu Psikiyatri Derg. 2017; 18.

27. Barth J, Bermetz L, Heim E, Trelle S, Tonia T. The current prevalence of child sexual abuse worldwide: a systematic review and meta-analysis. Int J Public Health. 2013; 58: 469-83.

28. Goldman JD, Padayachi UK. Some methodological problems in estimating incidence and prevalence in child sexual abuse research. J Sex Res. 2000; 37: 30514.

29. Sertdemir M, Kut B, Demirci Ş, et al. Konya İlinde Bir Çocuk ve Ergen Psikiyatrisi Kliniğinde Değerlendirilen Adli Olguların Sosyodemografik ve Klinik Özelliklerinin Geriye Dönük İncelenmesi. Turk J Child Adolesc Ment Health. 2020; 27: 27-32.

30. Anderson J, Martin J, Mullen P, Romans S, Herbison P. Prevalence of childhood sexual abuse experiences in a community sample of women. J Am Acad Child Adolesc Psychiatry. 1993; 32: 911-9. 